\title{
Respon Pertumbuhan dan Hasil Padi (Oryza sativa L.) terhadap Cekaman Suhu Tinggi
}

\author{
Growth and Yield Responses of Rice (Oryza sativa L.) to High Temperature Stress
}

\author{
Miftakhul Bakhrir Rozaq Khamid ${ }^{1 *}$, Ahmad Junaedi ${ }^{2}$, Iskandar Lubis ${ }^{2}$, dan Yoshinori Yamamoto \\ ${ }^{1}$ Program Studi Agroteknologi, Fakultas Pertanian, Universitas Singaperbangsa Karawang \\ Jl. H.S. Ronggowaluyo, Telukjambe Timur, Karawang, Indonesia \\ ${ }^{2}$ Departemen Agronomi dan Hortikultura, Fakultas Pertanian, Institut Pertanian Bogor \\ (Bogor Agricultural University), Jl. Meranti, Kampus IPB Darmaga, Bogor, 16680, Indonesia \\ ${ }^{3}$ Faculty of Agriculture and Graduate School of Kochi University, Japan
}

Diterima 25 Oktober 2018/Disetujui 29 Maret 2019

\begin{abstract}
Global climate change will imply to increase in atmospheric temperature, which can affect the sensitive stadia and decrease rice yield. The objective of this research was to study the growth and production of rice varieties under hightemperature stress. This research was conducted using a split-plot design under partitioned polyethylene house in order to create temperature differences among main-plots. The partitioned treatment successfully increased by $1.7^{\circ} \mathrm{C}$ of average temperature with a maximum temperature of $35.0^{\circ} \mathrm{C}$ (T1) and $37.6{ }^{\circ} \mathrm{C}$ (T2). Rice varieties, namely IR64, Ciherang, IPB-3S, Way Apo Buru, Jatiluhur, Menthik Wangi and Silugonggo were randomized as sub-plot. The results showed that increasing temperature had no significant effect on plant height, tiller number, SPAD-value, leaf area index, and crop growth rate, but significantly decreased 1,000 grains weight by $4.57 \%$ and harvest index by 20\%. The interaction between temperature and varieties significantly affected a percentage of a productive tiller and partially filled spikelets. Ciherang variety produced the lowest percentage of productive tillers on T2 by 57.6\%. Way Apo Buru variety produced the lowest percentage of partially filled spikelets on $\mathrm{T} 2$ by $3.01 \%$.
\end{abstract}

Keywords: climate, heat stress, productivity, rice field, varieties

\section{ABSTRAK}

Perubahan iklim global akan meningkatkan suhu atmosfer yang dapat mempengaruhi stadia sensitif dan menurunkan hasil padi. Tujuan penelitian ini adalah untuk mengkaji pertumbuhan dan hasil varietas padi pada kondisi cekaman suhu tinggi. Penelitian disusun menggunakan rancangan petak terbagi dan dilakukan di dalam rumah plastik polyethylene dengan perbedaan tinggi plastik penyekat agar tercipta perbedaan suhu sebagai perlakuan petak utama. Perlakuan penyekatan berhasil meningkatan suhu rata-rata sebesar $1.7^{\circ} \mathrm{C}$ antar petak utama, dengan suhu maksimum $35.0{ }^{\circ} \mathrm{C}$ (T1) dan $37.6{ }^{\circ} \mathrm{C}$ (T2). Varietas padi yang digunakan adalah IR64, Ciherang, IPB-3S, Way Apo Buru, Jatiluhur, Menthik Wangi dan Silugonggo yang diacak sebagai anak petak. Hasil penelitian ini menunjukkan bahwa perlakuan suhu secara tunggal tidak berpengaruh terhadap tinggi tanaman, jumlah anakan, nilai-SPAD, indeks luas daun, dan laju pertumbuhan tanaman (LPT), namun berpengaruh nyata terhadap penurunan bobot 1,000 butir sebesar 4.57\% dan indeks panen sebesar 20\%. Terjadi interaksi antara peningkatan suhu dan varietas terhadap persentase anakan produktif dan persentase jumlah gabah isi tidak penuh. Varietas Ciherang menghasilkan persentase anakan produktif terendah pada T2, yakni hanya sebesar 57.6\%. Varietas Way Apo Buru menghasilkan persentase gabah isi tidak penuh terendah pada perlakuan T2, yakni sebesar 3.01\%.

Kata kunci: cekaman panas, padi sawah, perubahan iklim, produktivitas, varietas

\section{PENDAHULUAN}

Perubahan iklim telah menyebabkan berubahnya pola musim, meningkatnya suhu udara dan terbatasnya sumber

\footnotetext{
* Penulis untuk korespondensi. e-mail: miftakhul.bakhrir@staff. unsika.ac.id
}

air sebagai akibat dari kekeringan lahan di Indonesia. Beath dan Beath (2010) menyatakan bahwa kondisi tersebut dapat mengancam keamanan pangan. Para ahli meramalkan bahwa pada akhir abad 21 akan terjadi peningkatan suhu antara 2$4{ }^{\circ} \mathrm{C}$ yang akan mempengaruhi dan mengancam produksi padi sebagai salah satu tanaman pangan. Peningkatan suhu tersebut dapat menurunkan produksi gabah sebesar 41\% (Ceccarelli et al., 2010; Krishnan et al., 2011) karena 
mempengaruhi proses pembungaan dan pengisian gabah (Xiao et al., 2011; Julia dan Dingkuhn, 2013).

Pertumbuhan dan hasil padi sensitif pada paparan suhu di atas $35^{\circ} \mathrm{C}$. Suhu di atas $35^{\circ} \mathrm{C}$ tersebut merupakan suhu kritis bagi stadia keluarnya bunga (antesis), yang pada akhirnya akan meningkatkan sterilitas. Pada stadia reproduktif dan pemasakan gabah, paparan suhu tinggi tersebut menyebabkan gabah mengapur, jumlah gabah berkurang dan bobot gabah isi menurun (Sun dan Huang, 2011). Selain itu, lonjakan suhu akan menurunkan tingkat viabilitas dan ukuran benih pada saat benih tersebut telah sampai pada stadia masak (Chen et al., 2016)

Varietas dan kultivar padi yang memiliki toleransi terhadap cekaman suhu tinggi memiliki beberapa mekanisme untuk menghadapi suhu tersebut. Kultivar yang toleran dapat memelihara ekspresi gen yang terkait dengan sintesis pati agar tidak terjadi bulir yang mengapur pada saat fase pemasakan (Tanamachi et al., 2016), adanya variasi waktu antesis pada genotipe padi yang berbeda sebagai mekanisme penghindaran terhadap saat terjadinya suhu tinggi (Julia dan Dingkuhn, 2012), karakter fisiologi seperti jumlah polen yang lebih banyak, morfologi organ reproduktif yang lebih terlindung, serta regulasi heat shock proteins yang telah banyak dipelajari (Jagadish et al., 2010; Xue et al., 2012).

Respon pertumbuhan padi yang toleran terhadap suhu tinggi masih sangat sedikit dipahami karena umumnya padi ditanam di daerah yang optimum bagi pertumbuhannya (Lu et al., 2013). Pemahaman yang mendalam tentang respon fisiologis tanaman terhadap suhu tinggi, mekanisme toleransi dan kemungkinan strategi untuk meningkatkan toleransi tanaman terhadap cekaman suhu sangat penting untuk diketahui guna mengantisipasi dampak perubahan iklim. Penelitian ini bertujuan untuk menjelaskan respon pertumbuhan dan hasil beberapa varietas padi utama di Indonesia yang ditanam pada cekaman suhu tinggi.

\section{BAHAN DAN METODE}

Penelitian dilaksanakan di Laboratoratorium Lapangan Riset Padi Kebun Percobaan Babakan, Dramaga, Bogor dan Laboratorium Analisis Tanaman Departemen Agronomi dan Hortikultura, IPB. Penanaman dilakukan di dalam rumah plastik polyethylene. Penelitian dilaksanakan pada bulan Januari sampai Juli 2013.

Bahan tanaman yang digunakan dalam penelitian ini adalah benih padi varietas Ciherang dan IR64 (padi sawah varietas unggul), IPB-3S (padi sawah tipe baru), Menthik Wangi (padi sawah varietas lokal), Way Apo Buru dan Silugonggo (padi sawah tipe amfibi), serta Jatiluhur (padi gogo). Rancangan penelitian yang digunakan adalah Rancangan Petak Terbagi dengan dua faktor perlakuan, yaitu perbedaan suhu dan varietas padi. Tanaman padi ditanam di dalam rumah plastik yang memiliki perbedaan suhu ratarata pada siang hari maksimum sebesar $1.7{ }^{\circ} \mathrm{C}$ diantara kedua petak utama. Perbedaan suhu diperoleh dengan melakukan perbedaan ketinggian dinding plastik penyekat pada masing-masing plot percobaan. Plot percobaan dengan plastik penyekat yang lebih tinggi, akan menghasilkan suhu yang lebih tinggi di dalamnya.
Pencatatan suhu dilakukan dengan menggunakan alat thermo recorder (TR-71U, TandD, Japan) yang dapat mencatat suhu udara dan tanah selama 24 jam dengan rentang 30 menit sekali. Suhu sebagai petak utama terdiri atas 2 taraf perlakuan suhu, yaitu : 1) suhu udara di dalam rumah plastik plot-1 (T1);2) suhu udara di dalam rumah plastik dengan peningkatan suhu rata-rata $\left(\mathrm{T} 1+\left(1.7{ }^{\circ} \mathrm{C}\right)\right)(\mathrm{T} 2)$; sedangkan 7 varietas merupakan anak petak. Kombinasi 2 faktor perlakuan menghasilkan 14 kombinasi perlakuan yang diulang 4 kali sehingga terdapat 56 unit percobaan.

Penelitian dilakukan di dalam rumah plastik yang memiliki 8 petak (bak) yang berukuran $3 \mathrm{~m} \mathrm{x} 4 \mathrm{~m}$. Petak dalam rumah plastik diberikan plastik penyekat untuk masing-masing perlakuan suhu untuk menciptakan perbedaan suhu. Jarak petak antar perlakuan petak utama 50 $\mathrm{cm}$ dan jarak petak antar ulangan $50 \mathrm{~cm}$. Petak percobaan masing-masing ditanami 7 varietas, tiap varietas terdiri atas 30 tanaman yang dibagi dalam 2 barisan (15 tanaman dalam tiap baris) dengan jarak tanam antar varietas $25 \mathrm{~cm}$ dan jarak tanam dalam baris $20 \mathrm{~cm}$. Penanaman tanaman pinggir di luar varietas yang diuji pada kedua sisi petak dilakukan untuk menghilangkan efek tanaman pinggir pada varietas yang diuji.

Pemeliharaan tanaman dilakukan dengan melakukan pemupukan dalam 3 tahap menggunakan pupuk dasar 37.5 $\mathrm{kg} \mathrm{N} \mathrm{ha}^{-1}, 36 \mathrm{~kg} \mathrm{P}_{2} \mathrm{O}_{5} \mathrm{ha}^{-1}$, dan $60 \mathrm{~kg} \mathrm{~K}_{2} \mathrm{O}_{\text {ha-1 }}$ yang diberikan pada 1 minggu setelah tanam (MST) dan untuk pemupukan kedua dan ketiga diberikan $37.5 \mathrm{~kg} \mathrm{~N}^{-1}$ pada 5 MST dan 9 MST. Pengendalian hama dan penyakit dilakukan sesuai kebutuhan di lapangan. Pemberian air dilakukan hingga panen dan berasal dari sumber yang sama untuk setiap petak utama. Pengairan dan penggenangan awal dilakukan dengan menjaga tinggi muka air yang dipertahankan $2.5 \mathrm{~cm}$ dari permukaan tanah.

Pengamatan non destruktif dilakukan pada 5 tanaman contoh dalam satu unit percobaan, sedangkan pengamatan destruktif dilakukan pada 1 tanaman contoh. Peubah yang diamati adalah tinggi tanaman $(\mathrm{cm})$ pada saat 8 MST; jumlah anakan pada $8 \mathrm{MST}$; nilai SPAD pada saat tanaman berbunga yang diukur menggunakan klorofil meter; indeks luas daun yang diukur dengan alat Licor 3000 pada saat tanaman berbunga; Laju Pertumbuhan Tanaman (LPT) pada saat berbunga hingga panen yang ditentukan dengan menimbang berat kering tanaman (Fitter dan Hay, 1998); persentase anakan produktif saat panen; jumlah dan persentase gabah isi penuh; jumlah dan persentase gabah isi tidak penuh; jumlah dan persentase gabah hampa per rumpun; bobot $(\mathrm{g})$ dan persentase gabah isi penuh; bobot (g) dan persentase gabah isi tidak penuh; bobot (g) dan persentase gabah hampa per rumpun; bobot seribu butir (g); dan indeks panen $=$ (bobot kering gabah/bobot kering tajuk). Panen dilakukan pada kondisi $85 \%$ gabah pada malai masak kuning, dan waktu panen tergantung varietas.

Hasil pengamatan tersebut kemudian diolah dan dianalisis dengan sidik ragam taraf kesalahan 5\% dan apabila pengaruh perlakuan nyata, maka dilanjutkan dengan uji jarak berganda Duncan (DMRT). 


\section{HASIL DAN PEMBAHASAN}

Sistem penyekatan yang diterapkan pada rumah plastik berhasil meningkatkan suhu pada plot T2 dengan peningkatan suhu harian rata-rata hingga mencapai $1.7^{\circ} \mathrm{C}$ dibandingkan dengan suhu dalam rumah plastik plot $\mathrm{T} 1$. Selain itu, rata-rata suhu maksimum yang dapat dihasilkan pada siang hari selama masa penelitian mencapai $37.6^{\circ} \mathrm{C}$ pada perlakuan plot $\mathrm{T} 2$, dan rata-rata suhu maksimum pada plot $\mathrm{T} 1$ adalah $35.0^{\circ} \mathrm{C}$ (Gambar 1). Pencatatan suhu tanah juga dilakukan dalam penelitian ini, namun nilainya tidak berbeda antar perlakuan.

Faktor tunggal perlakuan suhu dan interaksi suhu dengan varietas tidak berpengaruh terhadap jumlah anakan dan tinggi tanaman pada $8 \mathrm{MST}$, sedangkan varietas memberikan pengaruh yang sangat nyata terhadap kedua peubah tersebut (Tabel 1). Hasil penelitian yang dilakukan oleh Julia dan Dingkuhn (2013) juga menyatakan bahwa perlakuan suhu tinggi hingga $44{ }^{\circ} \mathrm{C}$ tidak memberikan pengaruh nyata terhadap jumlah anakan dan tinggi tanaman.

Perlakuan suhu dan interaksinya dengan varietas tidak memberikan pengaruh terhadap peubah nilai SPAD dan indeks luas daun pada saat berbunga, namun peubah tersebut dipengaruhi secara sangat nyata oleh perbedaan varietas (Tabel 1). Hal ini dimungkinkan oleh perbedaan karakteristik daun yang berbeda antar varietas. Varietas IR64 memiliki nilai SPAD yang tertinggi dibandingkan varietas lain. Nilai SPAD sangat dipengaruhi oleh umur tanaman, genotipe (varietas) dan ketebalan daun (Jinwen et al., 2011). Varietas Menthik Wangi merupakan varietas yang memiliki nilai tertinggi untuk peubah indeks luas daun, hal tersebut akan meningkatkan luasan kanopi untuk fotosintesis yang memfasilitasi peningkatan pengisian bulir pada padi.

Perlakuan suhu dan varietas secara tunggal serta interaksinya tidak mempengaruhi nilai peubah LPT pada saat berbunga hingga panen (Tabel 1). Hal ini dapat dimungkinkan karena bobot biomass pada penelitian ini tidak terpengaruh oleh perlakuan peningkatan suhu. Roy et al. (2012) menyatakan bahwa peningkatan biomass diperoleh dari peningkatan laju fotosintesis dan asimilasi bersih tanaman. Sedangkan Lu et al. (2013) menyatakan bahwa laju fotosintesis tanaman padi tidak dipengaruhi oleh perlakuan peningkatan suhu.

Interaksi perlakuan suhu dan varietas berpengaruh terhadap persentase anakan produktif. Varietas Ciherang menghasilkan persentase anakan produktif terendah yakni hanya sebesar $57.6 \%$, berbeda nyata terhadap varietas IPB-3S namun tidak berbeda nyata dengan varietas yang lain (Tabel 2). Hasil ini memberikan informasi yang sangat penting terhadap penanaman padi di Indonesia, karena varietas Ciherang merupakan varietas yang banyak ditanam oleh petani. Peningkatan suhu sebesar $1.7^{\circ} \mathrm{C}$ dapat menurunkan persentase anakan produktif sebesar $34.8 \%$. Varietas silugonggo diharapkan dapat menjadi varietas toleran cekaman suhu tinggi karena merupakan satu-satunya varietas yang mengalami peningkatan persentase anakan produktif akibat peningkatan suhu yang diberikan, yakni sebesar $5.5 \%$.

Perlakuan peningkatan suhu tidak berpengaruh terhadap jumlah gabah total dan persentase jumlah gabah hampa per rumpun (Tabel 3). Hal tersebut sesuai dengan

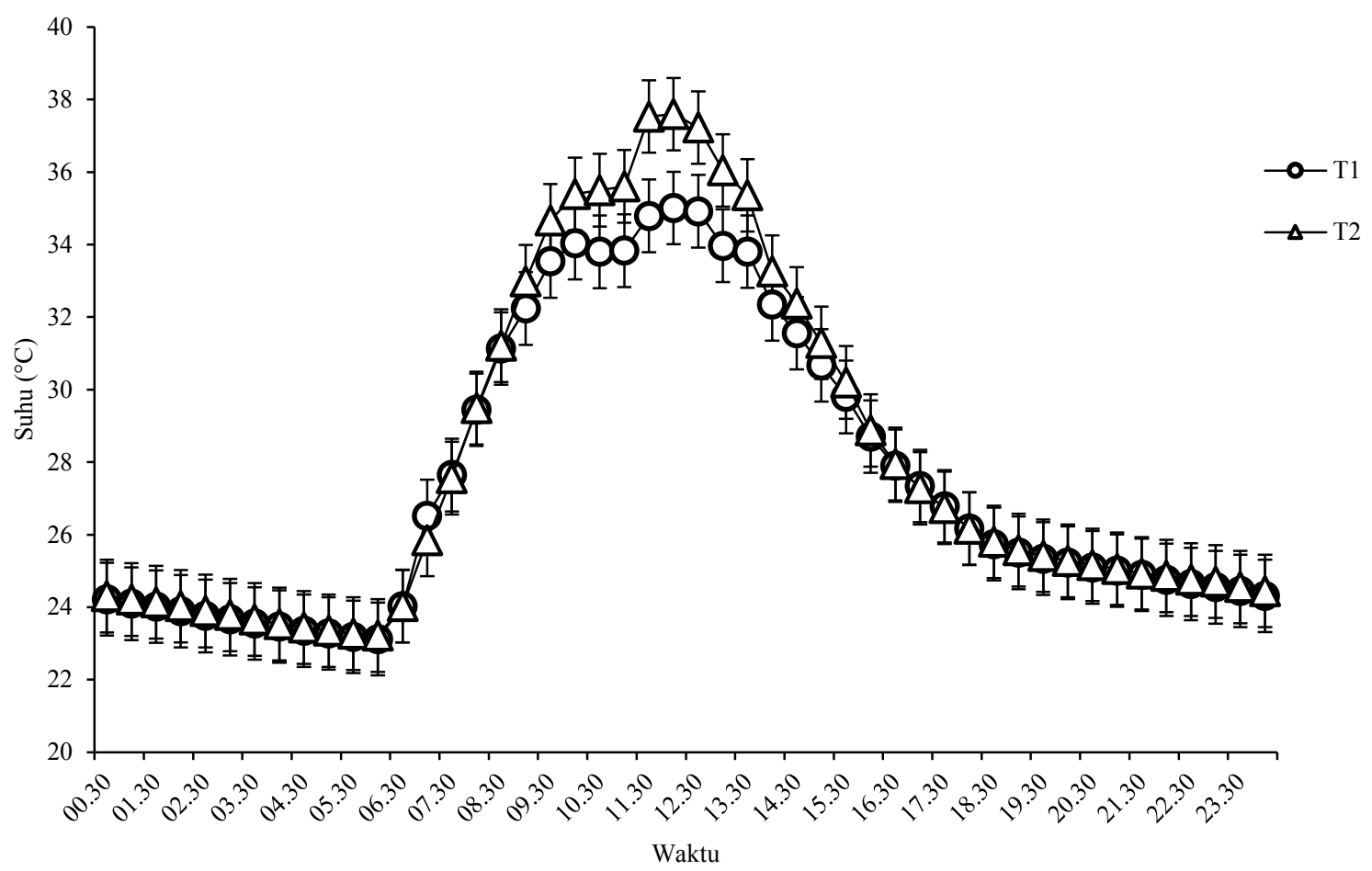

Gambar 1. Rata-rata suhu harian di dalam rumah plastik selama masa penelitian $\left(\mathrm{T} 1=\right.$ suhu maksimum rata-rata $35^{\circ} \mathrm{C} ; \mathrm{T} 2=\operatorname{suhu}$ maksimum rata-rata $37.6{ }^{\circ} \mathrm{C}$ ) 
Tabel 1. Pengaruh suhu dan varietas padi terhadap jumlah anakan dan tinggi tanaman pada 8 MST, serta nilai SPAD, indeks luas daun dan LPT pada saat berbunga

\begin{tabular}{|c|c|c|c|c|c|}
\hline Perlakuan & $\begin{array}{l}\text { Jumlah } \\
\text { anakan }\end{array}$ & $\begin{array}{l}\text { Tinggi tanaman } \\
(\mathrm{cm})\end{array}$ & $\begin{array}{l}\text { Nilai } \\
\text { SPAD }\end{array}$ & $\begin{array}{c}\text { Indeks } \\
\text { luas daun }\end{array}$ & $\begin{array}{c}\text { LPT } \\
\text { (g per hari) }\end{array}$ \\
\hline \multicolumn{6}{|l|}{ Suhu } \\
\hline $\mathrm{T} 1\left(35^{\circ} \mathrm{C}\right)$ & 6.5 & 90.77 & 40.33 & 2.67 & 0.44 \\
\hline $\mathrm{T} 2\left(37.6^{\circ} \mathrm{C}\right)$ & 6.9 & 89.50 & 39.70 & 2.36 & 0.30 \\
\hline \multicolumn{6}{|l|}{ Varietas } \\
\hline IR64 & $8.6 \mathrm{a}$ & $86.31 b$ & $43.69 a$ & $2.87 \mathrm{a}$ & 0.19 \\
\hline Ciherang & $6.5 \mathrm{~cd}$ & $84.52 b$ & $38.08 b c$ & $2.12 \mathrm{c}$ & 0.48 \\
\hline IPB-3S & $3.7 \mathrm{e}$ & $107.48 \mathrm{a}$ & $39.49 b c$ & $2.24 b c$ & 0.40 \\
\hline Way Apo Buru & $7.2 \mathrm{bc}$ & $85.42 b$ & $40.19 b$ & $2.08 \mathrm{c}$ & 0.21 \\
\hline Jatiluhur & $5.2 \mathrm{~d}$ & $107.28 \mathrm{a}$ & $38.09 b c$ & $2.78 \mathrm{ab}$ & 0.52 \\
\hline Menthik Wangi & $7.5 \mathrm{abc}$ & $74.97 \mathrm{c}$ & $37.62 \mathrm{c}$ & $3.00 \mathrm{a}$ & 0.41 \\
\hline Silugonggo & $8.2 \mathrm{ab}$ & $84.94 b$ & $42.94 \mathrm{a}$ & $2.53 \mathrm{abc}$ & 0.39 \\
\hline
\end{tabular}

Keterangan: Angka yang diikuti oleh huruf yang sama pada kolom yang sama untuk masing-masing perlakuan suhu dan varietas tidak berbeda nyata menurut uji DMRT pada taraf $\alpha$ 5\%. MST = Minggu Setelah Tanam; LPT = Laju Pertumbuhan Tanaman

Tabel 2. Pengaruh suhu dan varietas padi terhadap persentase (\%) anakan produktif

\begin{tabular}{lccc}
\hline \multirow{2}{*}{ Varietas } & \multicolumn{2}{c}{ Anakan produktif $(\%)$} & \multicolumn{2}{c}{ Persentase perubahan } \\
\cline { 2 - 4 } & $\mathrm{T} 1\left(35^{\circ} \mathrm{C}\right)$ & $\mathrm{T} 2\left(37.6^{\circ} \mathrm{C}\right)$ & $(-) 0.1$ \\
\hline IR64 & $73.5 \mathrm{abc}$ & $73.4 \mathrm{abc}$ & $(-) 34.8$ \\
Ciherang & $92.4 \mathrm{a}$ & $57.6 \mathrm{c}$ & $(-) 6.5$ \\
IPB-3S & $91.5 \mathrm{a}$ & $85.0 \mathrm{ab}$ & $(-) 7.5$ \\
Way Apo Buru & $77.2 \mathrm{abc}$ & $69.7 \mathrm{bc}$ & $(-) 16.7$ \\
Jatiluhur & $86.2 \mathrm{ab}$ & $69.5 \mathrm{bc}$ & $(-) 21.6$ \\
Menthik Wangi & $86.0 \mathrm{ab}$ & $64.4 \mathrm{c}$ & $(+) 5.5$ \\
Silugonggo & $69.1 \mathrm{bc}$ & $74.6 \mathrm{abc}$ & \\
\hline
\end{tabular}

Keterangan: Angka yang diikuti oleh huruf yang sama tidak berbeda nyata menurut uji DMRT pada taraf $\alpha 5 \%$. Tanda (+): terjadi peningkatan persentase; Tanda (-): terjadi penurunan persentase

hasil penelitian Mohammed dan Tarpley (2010) yang menyatakan bahwa dibutuhkan peningkatan suhu sebesar $5{ }^{\circ} \mathrm{C}$ untuk dapat meningkatkan jumlah gabah hampa. Supijatno et al. (2012) juga menduga bahwa suhu yang tinggi dalam rumah plastik dapat menyebabkan tingginya tingkat kehampaan. Perlakuan peningkatan suhu dapat berpotensi menurunkan jumlah gabah total sebanyak $12 \%$ dan meningkatankan persentase jumlah gabah hampa per rumpun sebesar $5.42 \%$.

Perlakuan peningkatan suhu menurunkan bobot seribu butir gabah seberat $1.07 \mathrm{~g}$ atau sekitar $4.6 \%$ lebih ringan dari perlakuan T1 (Tabel 3). Hal ini sejalan dengan hasil penelitian Shah et al. (2014) yang menyatakan bahwa bobot seribu butir gabah dari tanaman yang ditumbuhkan pada suhu normal akan secara nyata lebih tinggi dibandingkan tanaman padi yang tumbuh pada suhu $36{ }^{\circ} \mathrm{C}$. Ma et al. (2009) menyatakan bahwa penurunan tersebut terjadi karena ada hambatan pada saat proses pengisian gabah. Hal tersebut diduga pada perlakuan suhu tinggi akan terjadi peningkatan laju respirasi dan penurunan transfer fotosintat menuju gabah sebagai akibat kerusakan membran. Kim et al. (2011) juga menyatakan bahwa penurunan bobot gabah ini dipengaruhi oleh adanya fakta bahwa suhu tinggi akan memicu berkurangnya aktivitas source dan sink serta percepatan senesen pada malai. Selain itu, peningkatan suhu juga akan berpengaruh terhadap penurunan fertilitas polen pada saat pembungaan terjadi, dimana stadia ini merupakan stadia paling sensitif.

Interaksi perlakuan suhu dan varietas berpengaruh nyata terhadap persentase jumlah gabah isi tidak penuh. Varietas Way Apo Buru menghasilkan persentase gabah isi tidak penuh terendah pada perlakuan T2, yakni sebesar $3.01 \%$ serta berbeda nyata terhadap varietas Menthik Wangi dan IPB-3S namun tidak berbeda nyata terhadap varietas 
Tabel 3. Pengaruh suhu dan varietas padi terhadap jumlah gabah total per rumpun, persentase jumlah gabah hampa per rumpun dan bobot seribu butir

\begin{tabular}{lccc}
\hline Perlakuan & $\begin{array}{c}\text { Jumlah gabah total } \\
\text { per rumpun }\end{array}$ & $\begin{array}{c}\text { Persentase jumlah } \\
\text { gabah hampa per rumpun }(\%)\end{array}$ & $\begin{array}{c}\text { Bobot seribu butir } \\
(\mathrm{g})\end{array}$ \\
\hline Suhu & & & $23.42 \mathrm{a}$ \\
$\mathrm{T} 1\left(35^{\circ} \mathrm{C}\right)$ & 594.0 & 32.84 & $22.35 \mathrm{~b}$ \\
$\mathrm{~T} 2\left(37.6^{\circ} \mathrm{C}\right)$ & 522.7 & 34.62 & $21.53 \mathrm{~d}$ \\
Varietas & & & $23.25 \mathrm{bc}$ \\
IR64 & $466.0 \mathrm{bc}$ & 34.23 & $24.83 \mathrm{a}$ \\
Ciherang & $433.2 \mathrm{c}$ & 32.73 & $22.54 \mathrm{bcd}$ \\
IPB-3S & $629.8 \mathrm{ab}$ & 35.41 & $21.94 \mathrm{~cd}$ \\
Way Apo Buru & $546.1 \mathrm{bc}$ & 37.52 & $23.49 \mathrm{ab}$ \\
Jatiluhur & $766.7 \mathrm{a}$ & 27.36 & $21.91 \mathrm{~cd}$ \\
Menthik Wangi & $544.4 \mathrm{bc}$ & 31.25 & 37.63 \\
Silugonggo & $522.1 \mathrm{bc}$ & & \\
\hline
\end{tabular}

Keterangan: Angka yang diikuti oleh huruf yang sama pada kolom yang sama untuk masing-masing perlakuan suhu dan varietas tidak berbeda nyata menurut uji DMRT pada taraf $\alpha$ 5\%

yang lain (Tabel 4). Persentase gabah isi tidak penuh yang rendah ini diharapkan akan meningkatkan persentase gabah isi, sehingga varietas dapat dinilai toleran terhadap peningkatan suhu yang diberikan. Respon tanaman terhadap paparan suhu tinggi dapat berupa percepatan laju pengisian gabah, hal ini dapat memacu pemendekan waktu akumulasi bahan kering (Phan et al., 2013; Cao et al., 2016). Penurunan akumulasi bahan kering ini yang dapat menyebabkan hasil gabah yang diproduksi akan berukuran lebih kecil dan berisi tidak penuh atau tidak sempurna.

Perlakuan peningkatan suhu tidak mempengaruhi bobot gabah isi, total bobot gabah per rumpun dan bobot kering tajuk saat panen, namun berpotensi menurunkan bobot gabah isi sebesar $18.2 \%$ dan total bobot gabah per rumpun sebesar $19.08 \%$. Perlakuan suhu menurunkan indeks panen tanaman sebesar 20\% (Tabel 5). Nilai indeks panen akan semakin rendah apabila total bobot gabah per rumpun mengalami penurunan. Pengaruh perlakuan suhu terhadap indeks panen diduga merupakan akumulasi dari lebih besarnya penurunan total bobot gabah per rumpun dibandingkan penurunan bobot tajuk saat panen akibat peningkatan suhu, walaupun tidak nyata secara statistik. Penurunan nilai indeks panen ini sejalan dengan hasil penelitian $\mathrm{Lu}$ et al. (2013) yang menyatakan bahwa pada saat stadia pengisian biji, paparan suhu tinggi akan mempercepat kecepatan pengisian biji dan akan menyebabkan waktu pengisian biji menjadi lebih pendek. Hal ini menyebabkan bobot individu gabah akan berkurang dan lebih banyak terjadi akumulasi nutrien di tajuk pelepah. Oleh karena itu, paparan suhu tinggi selama proses produksi akan meningkatkan bobot tajuk dan menurunkan bobot gabah per rumpun, sehingga nilai indeks panennya akan semakin rendah.

Tabel 4. Pengaruh suhu dan varietas padi terhadap persentase (\%) jumlah gabah isi tidak penuh per rumpun

\begin{tabular}{lccc}
\hline \multirow{2}{*}{ Varietas } & \multicolumn{2}{c}{ Jumlah gabah isi tidak penuh per rumpun $(\%)$} & \multicolumn{2}{c}{ Persentase perubahan } \\
\cline { 2 - 3 } IR64 & $\mathrm{T} 1\left(35^{\circ} \mathrm{C}\right)$ & $\mathrm{T} 2\left(37.6^{\circ} \mathrm{C}\right)$ & $(+) 0.83$ \\
Ciherang & $5.36 \mathrm{bc}$ & $6.19 \mathrm{bc}$ & $(-) 9.74$ \\
IPB-3S & $15.64 \mathrm{a}$ & $5.90 \mathrm{bc}$ & $(-) 0.28$ \\
Way Apo Buru & $9.74 \mathrm{~b}$ & $9.46 \mathrm{~b}$ & $(-) 3.94$ \\
Jatiluhur & $6.95 \mathrm{bc}$ & $3.01 \mathrm{c}$ & $(-) 1.46$ \\
Menthik Wangi & $6.90 \mathrm{bc}$ & $5.44 \mathrm{bc}$ & $(+) 0.14$ \\
Silugonggo & $9.09 \mathrm{~b}$ & $9.23 \mathrm{~b}$ & $(+) 0.66$ \\
\hline
\end{tabular}

Keterangan: Angka yang diikuti oleh huruf yang sama tidak berbeda nyata menurut uji DMRT pada taraf $\alpha$ 5\%. Tanda (+): terjadi peningkatan persentase; Tanda (-): terjadi penurunan persentase 
Tabel 5. Pengaruh suhu dan varietas padi terhadap bobot gabah isi, total bobot gabah per rumpun, bobot tajuk panen dan indeks panen

\begin{tabular}{lcccc}
\hline Perlakuan & $\begin{array}{c}\text { Bobot gabah isi } \\
\text { per rumpun }(\mathrm{g})\end{array}$ & $\begin{array}{c}\text { Total bobot gabah } \\
\text { per rumpun }(\mathrm{g})\end{array}$ & $\begin{array}{c}\text { Bobot kering } \\
\text { tajuk }(\mathrm{g})\end{array}$ & Indeks panen \\
\hline Suhu & & & & $0.70 \mathrm{a}$ \\
$\mathrm{T} 1\left(35^{\circ} \mathrm{C}\right)$ & 8.13 & 9.54 & 15.94 & $0.56 \mathrm{~b}$ \\
T2 $\left(37.6{ }^{\circ} \mathrm{C}\right)$ & 6.65 & 7.72 & 14.89 & $0.48 \mathrm{~cd}$ \\
Varietas & & & $12.68 \mathrm{c}$ & $0.52 \mathrm{~cd}$ \\
IR64 & $5.89 \mathrm{~b}$ & $6.75 \mathrm{c}$ & $16.85 \mathrm{ab}$ & $0.78 \mathrm{ab}$ \\
Ciherang & $5.48 \mathrm{~b}$ & $6.60 \mathrm{c}$ & $15.54 \mathrm{abc}$ & $0.63 \mathrm{bcd}$ \\
IPB-3S & $8.70 \mathrm{ab}$ & $10.43 \mathrm{ab}$ & $12.25 \mathrm{c}$ & $0.87 \mathrm{a}$ \\
Way Apo Buru & $6.38 \mathrm{~b}$ & $7.48 \mathrm{bc}$ & $18.36 \mathrm{a}$ & $0.65 \mathrm{bc}$ \\
Jatiluhur & $11.74 \mathrm{a}$ & $13.09 \mathrm{a}$ & $18.84 \mathrm{a}$ & $0.45 \mathrm{~d}$ \\
Menthik Wangi & $7.77 \mathrm{~b}$ & $9.10 \mathrm{bc}$ & $13.38 \mathrm{bc}$ & \\
Silugonggo & $5.75 \mathrm{~b}$ & $6.98 \mathrm{c}$ & & \\
\hline
\end{tabular}

Keterangan: Angka yang diikuti oleh huruf yang sama pada kolom yang sama untuk masing-masing perlakuan suhu dan varietas tidak berbeda nyata menurut uji DMRT pada taraf $\alpha 5 \%$

\section{KESIMPULAN}

Peningkatan suhu harian sebesar $1.7{ }^{\circ} \mathrm{C}$ pada rataan suhu maksimum $35.0^{\circ} \mathrm{C}$ (plot T1) dan $37.6^{\circ} \mathrm{C}$ (plot T2) tidak berpengaruh terhadap peubah tinggi tanaman, jumlah anakan, nilai SPAD, indeks luas daun dan laju pertumbuhan tanaman, jumlah dan persentase gabah total per rumpun, bobot gabah isi per rumpun, total bobot gabah per rumpun dan bobot kering tajuk, namun berpengaruh nyata menurunkan bobot seribu butir sebesar $4.6 \%$ dan indeks panen sebanyak $20 \%$. Interaksi antara perlakuan suhu dan varietas berpengaruh nyata terhadap persentase anakan produktif. Persentase anakan produktif varietas Ciherang menghasilkan nilai terendah sebesar $57.6 \%$ pada perlakuan T2. Interaksi perlakuan suhu dan varietas juga berpengaruh nyata terhadap persentase jumlah gabah isi tidak penuh per rumpun. Persentase jumlah gabah isi tidak penuh per rumpun varietas Way Apo Buru menghasilkan nilai terendah sebesar $3.01 \%$ pada perlakuan T2. Varietas silugonggo diharapkan dapat menjadi varietas toleran cekaman suhu tinggi karena mengalami peningkatan persentase anakan produktif sebesar $5.5 \%$.

\section{UCAPAN TERIMA KASIH}

Penelitian ini mendapat dukungan pendanaan dari program BOPTN IPB tahun 2012-2013.

\section{DAFTAR PUSTAKA}

Beath, Mc.J.H., Mc.J. Beath. 2010. Environtmental Change and Food Security in China. Springer Dordrecht Heidelberg London, New York, USA.
Cao, Y.Y., Y.H. Chen, M.X. Chen, Z.Q. Wang, C.F. Wu, X. C. Bian, J.C. Yang, J.H. Zhang. 2016. Growth characteristics and endosperm structure of superior and inferior spikelets of indica rice under high temperature stress. Biologia Plantarum 60:532-542.

Ceccarelli, S., S. Grando, M. Maatougui, M. Michael, M. Slash, R. Haghparast, M. Rahmanian, M. Labdi, H. Mimoun, M. Nachit. 2010. Plant breeding and climate changes. J. Agri. Sci. 148:627-637.

Chen, C., K. Begcy, K. Liu, J.J. Folsom, Z. Wang, C. Zhang, H. Walia. 2016. Heat stress yields a unique MADS box transcription factor in determining seed size and thermal sensitivity. Plant Physiol. 171:606-622.

Fitter, A.H., R.K.M. Hay. 1998. Fisiologi Lingkungan Tanaman. Penerjemah: S. Andani, E.D. Purbayanti. Gajah Mada University Press, Yogyakarta, ID.

Jagadish, S.V.K., R. Muthurajan, R. Oane, T.R. Wheeler, S. Heuer, J. Bennett, P.Q. Craufurd. 2010. Physiological and proteomic approaches to address heat tolerance during anthesis in rice (Oryza sativa L.). J. Exp. Bot. 61:143-156.

Jinwen, L., Y. Jingping, L. Dongsheng, F. Pinpin, G. Tiantai, G. Changshui, C. Wenyue. 2011. Chlorophyll meter's estimate of weight-based nitrogen concentration in rice leaf is influenced by leaf thickness. Plant Prod. Sci. 14:177-183. 
Julia, C., M. Dingkuhn. 2012. Variation in time of day of anthesis in rice in different climatic environments. Europ. J. Agron. 43:166-174.

Julia, C., M. Dingkuhn. 2013. Predicting temperature induced sterility of rice spikelets requires simulation of crop-generated microclimate. Europ. J. Agron. 49:50-60.

Kim, J., J. Shon, C.K. Lee, W. Yang, W. Yoon, W.H. Yang, Y.G. Kim, B.W. Lee. 2011. Relationship between grain filling duration and leaf senescence of temperate rice under high temperature. Field Crops Res. 122: 207-213.

Krishnan, R., B. Ramakrishnan, K.R. Reddy, V.R. Reddy. 2011. High temperature effects on rice growth, yield and grain quality. Adv. Agron. 111:87-206.

Lu, G.H., Y.F. Wu, W.B. Bai, B. Ma, C.Y. Wang, J.Q. Song. 2013. Influence of high temperature stress on net photosynthesis, dry matter partitioning and rice grain yield at flowering and grain filling stages. J. Integrative Agric. 12:603-609.

Ma, Q.L., Y.S. Li, X.H. Tian, S.Z. Yan, W.C. Lei, N. Noboru. 2009. Influence of high temperature stress on composition and accumulation configuration of storage protein in rice. Sci. Agric. Sinica 42:714718 .

Mohammed, A.R., L. Tarpley. 2010. Effects of high night temperature and spikelet position on yield-related parameters of rice (Oryza sativa L.) plants. Eur. J. Agron. 33:117-123.

Phan, T.T.T., Y. Ishibashi, M. Miyazaki, H.T. Tran, K. Okamura, S. Tanaka, J. Nakamura, T. Yuasa, M.I. Inoue. 2013. High temperature induced repression of the rice sucrose transporter (OsSUT1) and starch synthesis-related genes in sink and source organs at milky ripening stage causes chalky grains. J. Agron. Crop Sci. 199:178-188.
Roy, K.S., P. Bhattacharyya, S. Neogi, K.S. Rao, T.K. Adhya. 2012. Combined effect of elevated $\mathrm{CO}_{2}$ and temperature on dry matter production, net assimilation rate, $\mathrm{C}$ and $\mathrm{N}$ allocations in tropical rice (Oryza sativa L.). Field Crops Res. 139:7179 .

Shah, F., L. Niea, K. Cui, Tariq, T. Shah, W. Wua, C. Chen, L. Zhu, F. Ali, S. Fahad, J. Huang. 2014. Rice grain yield and component responses to near $2{ }^{\circ} \mathrm{C}$ of warming. Field Crops Res. 157:98-110.

Sun, W., Y. Huang. 2011. Global warming over the period 1961-2008 did not increase high-temperature stress but did reduce low-temperature stress in irrigated rice across China. Agr. Forest Meteorol. 151:1193-1201.

Supijatno, M.A. Chozin, D. Sopandie, Trikoesoemaningtyas, A. Junaedi, I. Lubis. 2012. Evaluasi konsumsi air beberapa genotipe padi untuk potensi efisiensi penggunaan air. J. Agron. Indonesia 40:15-20.

Tanamachi, K., K. Matsuyama, M. Miyazaki, K. Matsuo, C. Suriyasak, A. Tamada, M.I. Inoue, Y. Ishibashi. 2016. Differential responses to high temperature during maturation in heat-stresstolerant cultivars of Japonica rice. Plant Prod. Sci. 19:300-308.

Xiao, Y.H., Y. Pan, L.H. Luo, H.B. Deng, G.L. Zhang, W.B. Tang, L.Y. Chen. 2011. Quantitative trait loci associated with pollen fertility under high temperature stress at flowering stage in rice (Oryza sativa L.). Rice Sci. 18:204-209.

Xue, D.W., H. Jiang, J. Hu, X.Q. Zhang, L.B. Guo, D.L. Zeng, G.J. Dong, G.C. Sun, Q. Qian. 2012. Characterization of physiological response and identification of associated genes under heat stress in rice seedlings. Plant Physiol. Biochemist. 61:46-53. 